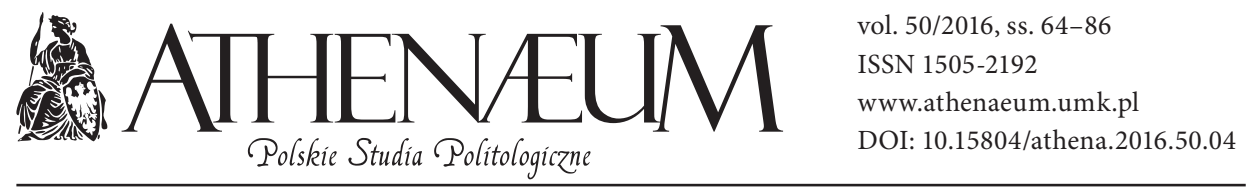

\title{
STRATEGICZNE SIŁY JĄDROWE FEDERACJI ROSYJSKIEJ
}

\author{
STRATEGIC NUCLEAR FORCES OF THE RUSSIAN FEDERATION
}

Jarosław Affek*

\begin{abstract}
ABSTRAKT
W artykule przedstawione zostały Strategiczne Siły Jądrowe Federacji Rosyjskiej (SSJ FR), ich rola $\mathrm{w}$ rosyjskiej doktrynie obronnej oraz zasadnicze wyposażenie i uzbrojenie. Celem artykułu jest dokonanie oceny potencjału bojowego SSJ, a także próba wywiedzenia stąd przyszłych możliwości oraz roli, jaką SSJ mają do odegrania w doktrynie obronnej Federacji Rosyjskiej w zmieniających się uwarunkowaniach międzynarodowych. Autor przedstawił na tle historycznym aktualny stan i potencjał rosyjskich SSJ. W artykule opisane zostały wszystkie trzy komponenty SSJ Rosji, czyli Wojska Rakietowe Strategicznego Przeznaczenia, strategiczne atomowe okręty podwodne - nosiciele rakiet balistycznych oraz Lotnictwo Dalekiego Zasięgu wraz z ich zasadniczymi systemami uzbrojenia. Scharakteryzowane zostały zasadnicze kategorie i typy środków przenoszenia strategicznej broni nuklearnej oraz wskazana ich prawdopodobna przyszłość. W tym kontekście podjęta została próba przedstawienia przedsięwzięć podejmowanych przez rosyjskie władze, mających na celu modernizację dotychczas posiadanych oraz wdrażanie nowo opracowywanych systemów uzbrojenia strategicznego.
\end{abstract}

- ABSTRACT

The article presents the Strategic Nuclear Forces (SNF) of the Russian Federation, its role in defensive doctrine and organization and armament. The author's intention is the evaluation of the SNF combat potential as well as determination of their future combat possibilities and role in the Russian military doctrine in the context of changing political situation in the world. The author has presented the history and actual state of Russian SNF. There are described all three components of the SNF: Missile Forces of Special Purpose, strategic nuclear-powered submarines with ballistic missiles, and finally long-range strategic bombers and their armament. Moreover, the main categories and types of nuclear weapon carrying system and perspective of its future development are defined. In this context, the author also tries to present the undertakings of Russian authorities connected with modernization of possessed means and introduction of new strategic weapon systems.

* Wyższa Szkoła Oficerska Wojsk Lądowych im. gen. Tadeusza Kościuszki we Wrocławiu, Instytut Dowodzenia. 
Słowa kluczowe: bezpieczeństwo narodowe, Rosja, broń jądrowa, odstraszanie nuklearne
Keywords: national security, Russia, nuclear weapon, nuclear deterrent

\section{WSTĘP}

Celem artykułu jest przedstawienie i ocena potencjału nuklearnego Federacji Rosyjskiej oraz kierunków jego rozwoju w najbliższej przyszłości. Autor sformułował hipotezę badawczą mówiącą, iż bez względu na okoliczności Federacja Rosyjska będzie zdeterminowana, aby utrzymać status mocarstwa nuklearnego. W związku z powyższym Rosja bez względu na koszty będzie dążyła do zachowania swojego potencjału nuklearnego na minimalnym niezbędnym poziomie. Za poziom ten autor uznaje ilość głowic i środków przenoszenia, gwarantującą utrzymanie parytetu w dziedzinie zbrojeń jądrowych z głównym adwersarzem Federacji Rosyjskiej, czyli Stanami Zjednoczonymi. Przy czym, zdając sobie sprawę ze stałego trendu ograniczania potencjału mocarstw nuklearnych po zimnej wojnie, autor zakłada, iż będzie on w obydwu tych państwach stopniowo redukowany - bazując na zasadzie wzajemności. Osiągnięcie celu badawczego następuje poprzez udzielenie odpowiedzi na pytania szczegółowe. Jak wyglądał potencjał Strategicznych Sił Jądrowych (SSJ) w momencie rozpadu ZSRR? Jakie uwarunkowania międzynarodowe oraz problemy wewnętrzne w nowo powstałym państwie miały wpływ na stan i rozwój SSJ. Jak obecnie przedstawia się stan broni jądrowej i środków jej przenoszenia w Rosji? I wreszcie jakie są perspektywy na przyszłość, szczególnie w kontekście dynamicznie zmieniającej się sytuacji w otoczeniu międzynarodowym Rosji? Niezbędne do udzielenia odpowiedzi na tak postawione pytania będzie zatem scharakteryzowanie środków przenoszenia broni nuklearnej składających się na aktualny potencjał Strategicznych Sił Jądrowych (SSJ) Federacji Rosyjskiej, a także prześledzenie zmian, jakie zaszły $\mathrm{w}$ ostatnich latach $\mathrm{w}$ rosyjskiej triadzie nuklearnej. W tym celu autor korzystał $\mathrm{z}$ informacji i danych zawartych $\mathrm{w}$ literaturze przedmiotu, artykułach prasowych (w tym w specjalistycznych czasopismach o tematyce militarnej), a także z opracowań wiodących w świecie ośrodków naukowych zajmujących się tematyką zbrojeń nuklearnych i badań nad pokojem. Wykorzystane zostały także otwarte źródła informacji, dostępne w Internecie w formie zapisu elektronicznego. Do badania oraz analizy zgromadzonych materiałów, jako podstawową metodę badawczą autor zastosował analizę źródeł wtórnych. 
29 sierpnia 1949 roku przeprowadzono w ZSRR pierwszą udaną próbę bomby atomowej ${ }^{1}$ oznaczoną kryptonimem RDS-1, a w Stanach Zjednoczonych jako Joe-1 w nawiązaniu do zdrobnienia imienia Stalina. 12 sierpnia 1953 roku na poligonie w Kazachstanie zdetonowano w ramach próby RDS-6s (Joe-4), pierwszą radziecką bombę termojądrową (Reed, Stillman, 2009, s. 34). I choć nie była to w pełni bomba termojądrowa ${ }^{2}$, to ZSRR umiejętnie wykorzystał to wydarzenie propagandowo. Z kolei w 1955 roku Rosjanie dokonali pierwszego zrzutu bomby atomowej z bombowca Tu-16 i wkrótce ten sposób wykonywania strategicznych uderzeń jądrowych stał się podstawowym w ZSRR. Stan ten nie utrzymał się jednak długo, ponieważ równolegle trwał już intensywny rozwój nowych środków przenoszenia broni jądrowej - rakiet balistycznych. Prekursorami ich rozwoju były nazistowskie Niemcy, ale po II wojnie światowej zarówno Rosjanie, jak i Amerykanie szeroko korzystali z ich dorobku w tej dziedzinie. Pierwsze odpalenie jeszcze niemieckiej V-2 miało miejsce w październiku 1947 roku na poligonie Kapustin Jar (Mikołajczuk, 2003, s. 19). Rok później wystartowała rakieta R-1, będąca zbudowaną w ZSRR kopią V-2.

Na współczesne Strategiczne Siły Jądrowe Federacji Rosyjskiej (SSJ) składają się trzy zasadnicze komponenty: lądowy - Rakietowe Wojska Strategicznego Przeznaczenia (RWSN), sił powietrznych - Lotnictwo Dalekiego Zasięgu oraz sił morskich - atomowe okręty podwodne nosiciele pocisków balistycznych (OPARB). Łącznie, wliczając stan części personelu sił powietrznych oraz marynarki wojennej, liczą one 80 tys. żołnierzy (The Military Balance, 2013, s. 225).

\section{KOMPONENT LĄDOWY STRATEGICZNYCH SIŁ JĄDROWYCH - RAKIETOWE WOJSKA STRATEGICZNEGO PRZEZNACZENIA}

Historycznie ich powstanie można wywodzić z drugiej połowy lat 50. XX wieku. Wówczas to w 1956 roku, rozpoczęto wprowadzanie na uzbrojenie rakiet $\mathrm{R}-5 \mathrm{M}$ o zasięgu $1200 \mathrm{~km}$. Była to pierwsza radziecka rakieta przystosowana do

\footnotetext{
1 Była to kopia amerykańskiej bomby Fat Man zrzuconej na Nagasaki.

2 Bomba była skonstruowana według innych zasad niż amerykańskie bomby termojądrowe, gdyż Rosjanie nie odkryli jeszcze zasad konstrukcji w pełni termojądrowej bomby. Nie zgłębiając się w szczegóły techniczne, osiągnęła ona dosyć niską moc wybuchu, gdyż większość energii ulotniła się w formie promieniowania. Było to zaledwie kilka procent mocy wybuchu pierwszej amerykańskiej bomby-instalacji termojądrowej o mocy 10,4 Mt zdetonowanej 1 listopada 1952 roku. Pierwsza radziecka „prawdziwa” bomba termojądrowa została zdetonowana 22 listopada 1955 roku w ramach próby RDS-37.
} 
przenoszenia ładunków jądrowych. Późniejszy pokaz uzbrojenia rakietowego zorganizowany w 1958 roku dla ówczesnych władz ZSRR wywarł olbrzymie wrażenie i zaowocował powołaniem 17 grudnia 1959 roku Rakietowych Wojsk Strategicznego Przeznaczenia (RWSN - Rakietnych Wojsk Strategiczeskowo Naznaczenia).

Na przełomie lat 1950/1960 miał miejsce szczególnie intensywny rozwój techniki rakietowej oraz jej umasowienie. W tym też okresie rakiety balistyczne stopniowo uzyskiwały prymat nad bombowcami. Ich wielkim zwolennikiem był sekretarz generalny KPZR Nikita S. Chruszczow, który promował je kosztem lotnictwa bombowego dalekiego zasięgu. W 1959 roku wprowadzono do eksploatacji niewielką ilość pierwszych rakiet międzykontynentalnych typu R-7³.W 1961 roku zaczęto wprowadzać na uzbrojenie rakiety R-16 konstrukcji M. Jangiela. Osiągały one zasięg 11-13 tys. km i były pierwszą konstrukcją wykorzystywaną operacyjnie w większych ilościach (26 szt.). W ramach postępującego wyścigu zbrojeń, równolegle z wprowadzaniem nowych typów pocisków balistycznych, formowano jednostki wojsk rakietowych. Początkowo bowiem to Stany Zjednoczone miały w tej dziedzinie przewagę nad ZSRR, którą udało się zniwelować dopiero na początku lat 70-tych.

Współczesne nam Rakietowe Wojska Strategicznego Przeznaczenia (RWSN) powstały formalnie w 1997 roku, w wyniku podjętej wcześniej reorganizacji sił zbrojnych. Zostały wówczas połączone z Wojenno-Kosmicznymi Siłami oraz Wojskami Obrony Rakietowo-Kosmicznej. Z kolei w 2001 roku utworzono na ich bazie dwa rodzaje wojsk, RWSN oraz Wojska Kosmiczne ${ }^{4}$. RWSN, będąc samodzielnym rodzajem wojsk, podlegają bezpośrednio Ministrowi Obrony FR. Ich główną siłą uderzeniową są trzy Armie Rakietowe, mające w swoim składzie dwanaście Dywizji Rakietowych (MO FR, 2013). Plany sprzed jeszcze kilku lat zakładały stopniową redukcję ilości dywizji do ośmiu - dziewięciu, jednak wobec zaogniania się stosunków międzynarodowych na linii wschód - zachód zostały

\footnotetext{
3 Były to rakiety konstrukcji Siergieja Korolowa, pierwotnie wykorzystywane do wynoszenia sztucznych satelitów w radzieckim programie kosmicznym. Najprawdopodobniej w RWSN znajdowały się w eksploatacji jedynie cztery egzemplarze tych rakiet.

${ }^{4}$ Po dołączeniu elementów obrony przeciwrakietowej ze struktur sił powietrznych Rosji (WWS Rosji), z dniem 1 grudnia 2011 roku Wojska Kosmiczne przemianowano na Wojska Obrony Powietrzno-Kosmicznej. Ich zadaniem jest stworzenie zintegrowanego systemu rozpoznania, obrony kosmicznej i przeciwrakietowej oraz kierowanie jego działaniami. Rosjanie sami wyrażają wątpliwości co do sensu ich tworzenia, gdyż dotychczas Wojska Kosmiczne nie dysponowały żadną bronią, a jedynie systemami obserwacji i rozpoznania. Scalenie tych elementów oraz sprawne kierowanie ich działalnością stanowi dla sił zbrojnych Rosji poważne wyzwanie.
} 
one odłożone w czasie. Dywizje rakietowe posiadają strukturę pułkową i są związkami taktycznymi zdolnymi do samodzielnego wypełniania zadań bojowych. Pułki z kolei są podstawowymi jednostkami bojowymi odpowiedzialnymi za prowadzenie działań bojowych - wystrzeliwanie rakiet balistycznych.

U schyłku ZSRR głównym uzbrojeniem RWSN były dwustopniowe międzykontynentalne pociski balistyczne RS-20 kompleksu Wojewoda (inne ros. oznaczenie R-36, w kodzie NATO: SS-18 Satan). Ich produkcję w wersji R-36 podjęto w 1965 roku i od tego czasu były systematycznie rozwijane i modyfikowane. Ze względu na zakres zmian kolejne wersje tych rakiet, mimo dzielenia wspólnej nazwy, były w praktyce zupełnie nowymi konstrukcjami. W 1975 roku wprowadzono zmodernizowaną R-36M, a od 1983 roku wdrażano R-36MUTTCh. Ostatnim wariantem tej ciężkiej rosyjskiej rakiety jest przyjęta na uzbrojenie w 1988 roku R-36M2 (RS-20W), która w dalszym ciągu znajduje się w eksploatacji (Woskriesieńskij, 2015, s. 11). Jest to największa i najcięższa rakieta balistyczna w Rosji. Osiąga długość 34,3 m i masę własną 211 ton. Dzięki potężnym silnikom na paliwo ciekłe może przenieść ładunek bojowy o masie 8,8 tony na odległość do 11,5, a przy mniejszej jego masie nawet 16 tys. km. Zgodnie $\mathrm{z}$ deklaracjami rosyjskich władz z końca 2012 roku, w użyciu operacyjnym (pełniąc dyżury bojowe) znajdowało się 55 rakiet w wyrzutniach - silosach, każda uzbrojona w 10 niezależnie naprowadzanych głowic jądrowych (MO FR, 2013) o mocy 550 kt.

Kolejnym typem rakiety wykorzystywanym operacyjnie w RWSN jest RS-18W (inne ros. oznaczenie UR-100NUTTCh ${ }^{5}$, w kodzie NATO: SS-19 Stiletto). Przy długości 24,3 m (występowało kilka wariantów różniących się nieznacznie wymiarami i osiągami) umożliwiała ona przeniesienie sześciu niezależnie naprowadzanych głowic $\left(\mathrm{MIRV}^{6}\right)$ na odległość do 10 tys. km, z dokładnością trafienia 250-500 m $\left(\mathrm{CEP}^{7}\right)$. W 2012 roku Rosja deklarowała utrzymywanie

${ }^{5}$ Jest to rakieta trzeciej generacji, jednak w ZSRR, a potem w Rosji systematycznie co kilka lat wprowadzano nowsze ulepszone wersje rakiet, bazujące na starszych konstrukcjach. Podobnie jak w kompleksie Wojewoda (rakiety R-36, R36M i R-36M2), także tu produkowane były kolejno UR-100, UR-100N i UR-100NUTTCh. Ta ostatnia (UTTCh - w jęz. pol. ulepszone charakterystyki taktyczno-techniczne) jest ukoronowaniem rozwoju tej rodziny rakiet. Mimo ich wieku, po zrealizowaniu próbnych strzelań oraz przedłużeniu resursów o 10 lat, rakiety ostatniej serii w dalszym ciągu znajdują się w systemie dyżurów bojowych.

${ }^{6} \mathrm{MIRV}$ - ang. multiple independently targetable reentry vehicle.

${ }^{7}$ Circular-error probable (CEP) - średni kołowy błąd trafienia, przyjmuje się, że 50\% wystrzelonych pocisków rakietowych, w przypadku omawianego typu, powinno upaść w kole o średnicy 250 lub 500 m; przyjęte dane różnią się zależnie od tego, czy są podawane przez odpowiednio źródła amerykańskie, czy rosyjskie. 
w dyżurach bojowych 35 rakiet w wyrzutniach - silosach, każda z 6 głowicami jądrowymi. Jako że były one produkowane w latach 1979-1984, w najbliższych latach planowane jest ich wycofanie $\mathrm{z}$ arsenałów jądrowych.

Począwszy od 1989 roku, do eksploatacji zaczęła wchodzić RS-22 kompleksu Mołodiec (inne ros. oznaczenie RT-23UTTCh, w kodzie NATO SS-24 Scalpel). Jest to rakieta 4 . generacji, która powstała w odpowiedzi na intensywny rozwój arsenałów nuklearnych USA, w tym opracowywanych w ramach programu MX nowych rakiet bazowania lądowego (przyszły LGM-118 Peacekeeper) oraz rakiet balistycznych bazowania morskiego Trident. RS-22 występowała w dwóch wersjach, stacjonarnej, bazującej w podziemnych silosach oraz mobilnej, przewożonej i wystrzeliwanej ze składu kolejowego. W tym drugim wariancie składy kolejowe (pułki rakiet) miały wykonywać patrole po bezkresnych obszarach ZSRR, będąc jednocześnie trudne do namierzenia i w zasadzie niemożliwe do zniszczenia uderzeniem wyprzedzającym, co było największą wadą pozycji stacjonarnej. Teoretycznie rakiety mogły być odpalane w dowolnym punkcie patrolu, jednak w praktyce były wybierane i przygotowywane odpowiednie miejsca na trasie. Za optymalny sposób uznawano wystrzeliwanie rakiet właśnie z nich. Wymiary i osiągi rakiety były zbliżone do wcześniej omawianej RS-18, z tym że przenosiła ona 10 głowic. Obecnie RS-22 nie znajdują się już w użyciu.

Kolejny typ rakiety balistycznej, RS-12M (inne ros. oznaczenie RT-2PM Topol, w kodzie NATO SS-25 Sickle) jest przedstawicielem 4. generacji rakiet i została wprowadzona do użytku w 1988 roku. Można przyjąć, iż jest odpowiednikiem amerykańskiej rakiety Minuteman. Jest to trzystopniowa rakieta o długości 21,5 $\mathrm{m}$, napędzana paliwem stałym. Przenosi pojedynczą głowicę jądrową o mocy 550 kt na odległość do 11 tys. km. Jest to pierwszy pocisk międzykontynentalny, wykorzystujący wyrzutnię mobilną o trakcji kołowej. Rozwiązanie to jest droższe niż z wykorzystaniem silosów stacjonarnych, lecz gwarantować ma większą ochronę przed wyprzedzającym atakiem rakietowym przeciwnika, dając możliwość rozśrodkowania (zmiany położenia) wyrzutni. Mankamentem takiego rozwiązania jest to, iż przy dużych rozmiarach wyrzutni, istnieją jednak poważne ograniczenia jej mobilności, a dostępność terenu, drożni i ukryć dla tego systemu jest ograniczona. Zgodnie z deklaracjami rosyjskimi z 2012 roku w użyciu (status operacyjny) znajduje się 150 rakiet na wyrzutniach mobilnych, natomiast według The Military Balance 2013 (2013, s. 225) jest ich 120.

RS-12M2 (RS-12M1) kompleksu Topol M (inne ros. oznaczenie RT-2PM2 Topol M, w kodzie NATO SS-27 Sickle Mod. 1) jest wersją rozwojową Topoli i jednocześnie przedstawicielką 5. pokolenia rakiet balistycznych. Próbna eks- 
ploatacja tego systemu została podjęta w 1997 roku. Jest to pierwsza rakieta stworzona samodzielnie w Rosji i występuje w dwóch wersjach. RS-12M2 startuje z wyrzutni stacjonarnej w silosach podziemnych, często dostosowanych po wycofanych $z$ użycia starszych R-36M lub UR-100NUTTCh. Ta wersja znajduje się w dyżurach bojowych od 2000 roku. Z kolei RS-12M1 bazuje na wyrzutni mobilnej o trakcji kołowej, pełniąc dyżury bojowe od 2006 roku. Swym zaawansowaniem technicznym odpowiada ona amerykańskim rakietom Minuteman III. Przy długości 21 m SS-27 przenosi jedną głowicę jądrową o mocy 0,5 Mt na dystans 11,5 tys. km. W 2012 roku Rosja deklarowała utrzymywanie w statusie operacyjnym 18 rakiet na wyrzutniach mobilnych oraz 56 w silosach.

Najnowszym typem lądowych rosyjskich rakiet balistycznych jest RS-24 Jars (SS-27 Sickle Mod. 2) na wyrzutni mobilnej. Testowe odpalenia tych rakiet odbywały się w 2007 roku, a od 2010 roku RS-24 zaczęły być wprowadzane do uzbrojenia. W 2012 roku jedna z dywizji RWSN miała ich na stanie 18 sztuk, a w 2015 roku mają znaleźć się one na wyposażeniu trzech dywizji rakietowych. Od strony formalnej jest to nowa konstrukcja, która powstała w odpowiedzi na jednostronne wycofanie się USA z układu $\mathrm{ABM}^{8}$. W rzeczywistości RS-24 jest modyfikacją Topol M, polegającą głównie na zastosowaniu nowocześniejszych komponentów i przystosowaniu do przenoszenia 3 lub 6 głowic jądrowych. Rakiety te obecnie są produkowane w miejsce mobilnych RS-12M1. Wobec ostatnich deklaracji rosyjskich decydentów wysoce prawdopodobne jest pojawienie się wkrótce systemu Jars w wariancie stacjonarnym (bazującego w silosach), a także mobilnym w ramach składów kolejowych.

Według oświadczenia dowódcy RWSN gen. S. Karakajewa z grudnia 2012 roku, w Rosji prowadzi się prace nad zupełnie nową strategiczną 100-tonową rakietą, która będzie w stanie pokonać każdy obecny i przyszły system antyrakietowy. Ma być ona napędzana silnikami na ciekły materiał pędny i gwarantować niezwykłą precyzję uderzeń. Zakłada się też wykorzystywanie konwencjonalnych głowic bojowych, co dzięki spodziewanej precyzji pozwoli na bardziej elastyczne

8 Zgodnie z ustaleniami układu START II podpisanego w Moskwie 3 stycznia 1993 roku przez USA i Rosję zabronione było stosowanie pocisków balistycznych z wieloma niezależnie naprowadzanymi głowicami jądrowymi (MIRV). Rosyjska Duma ratyfikowała START II 14 kwietnia 2000 roku, lecz już 13 czerwca 2002 roku Rosja wycofała się z układu w odpowiedzi na wycofanie się Stanów Zjednoczonych z układu ABM. Rosjanie odbierali to jako zagrożenie dla swojego potencjału odstraszania nuklearnego, gdyż ewentualnie rozwijane w USA systemy przeciwrakietowe mogłyby wg nich z łatwością zwalczać rakiety jednogłowicowe i tym samym zachwiać strategiczną równowagę. Wprowadzenie nowych rakiet wielogłowicowych ma być remedium na to zagrożenie i jednocześnie formą nacisku na Amerykanów podczas rozmów rozbrojeniowych. 
używanie rakiety, już nie tylko w ramach systemu odstraszania nuklearnego. Według oficjalnych deklaracji miałyby one wchodzić do uzbrojenia od 2019 roku i zastępować ciężkie wielogłowicowe SS-18 Satan, wymieniana jest przy tym nazwa Sarmat.

\section{KOMPONENT POWIETRZNY STRATEGICZNYCH SIŁ JĄDROWYCH}

Komponent powietrzny SSJ wchodzi w skład Lotnictwa Dalekiego Zasięgu (LDZ). Dowództwo LDZ podlega Ministrowi Obrony, natomiast operacyjną kontrolę nad nim sprawuje Dowództwo Rosyjskich Sił Powietrznych. Wśród głównych zadań lotnictwa strategicznego wymienia się w pierwszej kolejności niszczenie baz lotniczych, kompleksów rakietowych bazowania lądowego oraz lotniskowców i towarzyszących im okrętów przeciwnika. W dalszej kolejności jako potencjalne cele wymieniane są m.in. obiekty wojenno-przemysłowe oraz centra administracyjno-polityczne.

Główną siłę uderzeniową Lotnictwa Dalekiego Zasięgu (dawniej 37. ALDZ - Armia Lotnicza Dalekiego Zasięgu $)^{9}$ stanowią dwie bazy lotnicze (dywizje). Są to 6950. Baza Lotnicza (Russia Air Forces, 2014, s. 9) w m. Engels (dawna 22. Dywizja Ciężkich Bombowców) z samolotami Tu-95MS i Tu-160 oraz 6952. Baza Lotnicza w m. Ukrainka (dawna 326. Dywizja Ciężkich Bombowców) z Tu-95MS (russianforces.org/aviation/, 2013). Ogółem dysponują one łącznie 16 bombowcami Tu-160 oraz 58 Tu-95MS. Ponadto w ośrodkach szkoleniowych i doświadczalnych znajdują się prawdopodobnie jeszcze dwa egzemplarze Tu-160 oraz około dziesięć Tu-95MS ${ }^{10}$. Do lotnictwa strategicznego zaliczane są też cztery grupy lotnicze (dawniej dywizje) wyposażone w ciężkie samoloty bombowe Tu-22M3. Głównym uzbrojeniem samolotów lotnictwa strategicznego jest

\footnotetext{
9 Wobec reform wprowadzanych w rosyjskich siłach powietrznych od 2011 roku, rozwiązane zostały Armie Lotnicze (w tym prawdopodobnie i 37. ALDZ), a w ich miejsce powstały Bazy Lotnicze różnej rangi. W miejsce rozwiązywanych dywizji i pułków, powstają grupy lotnicze i eskadry podporządkowane bazom.

${ }^{10}$ Według informacji z 2009 roku przekazanych w ramach wymiany danych zgodnie z ustaleniami układu START, Rosjanie posiadali 77 bombowców, z czego 63 to Tu-95MS a 14 to Tu-160. Z kolei dane przedstawione przez Rosjan w marcu 2012 roku, w ramach wymiany informacji do układu New START mówią, iż Rosja dysponuje 66 bombowcami strategicznymi, z tego 55 Tu-95MS a 11 Tu-160. Można zakładać iż część samolotów została wycofana ze służby operacyjnej np. dla wykonania koniecznych remontów, modernizacji, do ośrodków doświadczalnych etc. i przez to nie jest wykazywana w oficjalnych statystykach, jako niebędąca w gotowości bojowej.
} 
około 810 sztuk strategicznych rakiet manewrujących z głowicami nuklearnymi. Szacuje się, iż 200-300 z nich znajduje się bezpośrednio w bazach przy bombowcach, zdolne do natychmiastowego użycia (SIPRI Yearbook, 2013, s. 295). Pozostałe zostały zmagazynowane w centralnych składach z dala od nosicieli.

Zasadniczym wyposażeniem lotnictwa strategicznego są bombowce Tu-95MS (w kodzie NATO: Bear H). Samolot ten, w swej pierwotnej postaci Tu-95 wprowadzony do służby w 1957 roku, był przeznaczony do wykonywania klasycznych ataków bombami jądrowymi na terytorium Stanów Zjednoczonych. W związku z dynamicznym rozwojem kierowanych rakietowych pocisków przeciwlotniczych okazało się, iż przedarcie się bombowca bezpośrednio nad cel ataku staje się coraz mniej realne. Opracowano wówczas wersję $\mathrm{K}$, wyposażoną w potężny radar na dziobie i przenoszącą dwunastotonową rakietę Ch-20 o zasięgu 650 $\mathrm{km}$, uzbrojoną w pojedynczą głowicę jądrową. Kolejna wersja bombowca mogła zabierać trzy lżejsze i nowocześniejsze pociski Ch-22M, każdy o masie 5,8 tony i uzbrojony w głowicę jądrową o mocy 150 kt. Rakiety te osiągały zasięg $500 \mathrm{~km}$ przy prędkości maksymalnej $3600 \mathrm{~km} / \mathrm{h}$.

We współcześnie użytkowanej wersji Tu-95MS jego uzbrojeniem jest 6 lub 16 samosterujących pocisków Ch-55 (w kodzie NATO AS-15 Kent), wprowadzonych do uzbrojenia w 1981 roku. Ich zasięg wynosi $2500 \mathrm{~km}(3000 \mathrm{~km}$ z dodatkowymi konforemnymi zbiornikami paliwa). Strategiczna rakieta samosterująca Ch-55 powstała w odpowiedzi na amerykańską konstrukcję AGM-86 ALCM i służy do niszczenia stacjonarnych celów o znanym położeniu. Jej układ naprowadzania wykorzystuje system nawigacji bezwładnościowej, wsparty - dla zwiększenia precyzji układem korekcji według rzeźby terenu $\mathrm{z}$ radarem nawigacyjnym DISS. Porównuje on uzyskany przez radar obraz terenu na trasie przelotu z wprowadzoną do pamięci komputera cyfrową mapą. Dzięki temu uzyskuje się dokładność trafienia do $100 \mathrm{~m}$, co jest wartością wystarczającą dla rakiety z głowicą jądrową o mocy 200 kt, bo tylko w takim wariancie występuje Ch-55. Rakieta wykonuje lot do celu po zadanej trasie na wysokości kilkudziesięciu metrów z prędkością 0,5-0,77 Ma. Dodatkowo w czasie lotu do celu kilkakrotnie zmienia kierunek, jest więc obiektem bardzo trudnym do zwalczania.

Ze względu na zakładaną perspektywiczność nowego uzbrojenia podjęto budowę nowych płatowców Tu-95, a cały system przyjęto do uzbrojenia w końcu 1983 roku. Wariant Tu-95MS6 zabiera sześć rakiet w komorze bombowej. Wariant Tu-95MS16 posiada nowocześniejsze wyposażenie elektroniczne, częściowo zaadaptowane z Tu-160 i może przenosić dodatkowo 10 rakiet podwieszanych pod skrzydłami (także nowszych Ch-55SM). Podwieszenie dodatkowych rakiet 
poza komorą bombową odbija się jednak na osiągach samolotu, przede wszystkim na zasięgu (6500 km zamiast $10500 \mathrm{~km})$. Tu-95MS dysponuje czterema silnikami turbośmigłowymi, dzięki którym osiąga bardzo wysoką prędkość $830 \mathrm{~km} / \mathrm{h}$ oraz zasięg ponad 14 tys. $\mathrm{km} \mathrm{z}$ jednym tankowaniem w powietrzu. Umożliwia mu to realizowanie długotrwałych patroli wzdłuż wybrzeży Stanów Zjednoczonych, z uzbrojeniem gwarantującym możliwość wykonania nuklearnego ataku na prawie każdy obiekt na ich terytorium.

W 1987 roku Związek Radziecki rozpoczął wdrażanie do służby nowego strategicznego samolotu bombowego Tu-160 (w kodzie NATO: Blackjack). Miał on być następcą Tu-95MS i odpowiednikiem amerykańskiego B-1A Lancer, konstruowano go bowiem według podobnych założeń. Pierwsze seryjne samoloty w ilości 19 sztuk były w posiadaniu jednej tylko jednostki, pułku bombowców ciężkich w Priłukach w Ukraińskiej SRR i wobec rozpadu ZSRR przejęła je Ukraina. Rosjanie utworzyli w bazie Engels własny pułk bombowców ciężkich, wyposażony do 1994 roku w 6 samolotów ukończonych spośród będących w różnej fazie produkcji w zakładzie w Kazaniu. Do tego doszło odkupionych z Ukrainy w latach 1999-2000 osiem samolotów ${ }^{11}$. Z kolei w 2000 i 2008 roku ukończono i przekazano wojsku jeszcze po jednym egzemplarzu ze znajdujących się w zaawansowanym stadium budowy w fabryce. Kolejny bombowiec przekazano wojsku w 2006 roku z ośrodka doświadczalnego w Żukowskim. Przy stracie jednej maszyny w katastrofie lotniczej w 2003 roku, stan ilościowy Tu-160 ustabilizował się na poziomie 16 sztuk eksploatowanych w 121. Gwardyjskim Pułku Ciężkich Bombowców w Engelsie. Z reguły kilka sztuk tych samolotów stale znajduje się w remontach, przeglądach lub modernizacji, skutkiem czego wyłączone są ze służby operacyjnej w strategicznych siłach jądrowych.

Tu-160 jest czterosilnikowym samolotem o napędzie odrzutowym, wykorzystującym układ zmiennej geometrii skrzydeł i osiągającym prędkość maksymalną $2200 \mathrm{~km} / \mathrm{h}$ na dużej wysokości. Teoretycznie może on przenosić różnego rodzaju uzbrojenie, zarówno atomowe, jak i konwencjonalne, osiągając zasięg 14 tys. km. W praktyce jedynym środkiem bojowym przenoszonym przez Tu-160 jest 12 sztuk rakiet Ch-55SM, rozmieszczanych w dwóch lukach bombowych. W niektórych opracowaniach podaje się, że mógł przenosić także do 24 sztuk taktycznych rakiet z głowicami jądrowymi Ch-15 o zasięgu do $300 \mathrm{~km}$. W praktyce jednak na żadnym $z$ samolotów w linii nie wykorzystano tej możliwości. Podstawowym zadaniem samolotu, podobnie jak Tu-95MS, jest prowadzenie dalekich patroli

${ }_{11}$ Pozostałe na Ukrainie egzemplarze zostały zezłomowane, przekazane na pomniki etc. 
i demonstrowanie gotowości rosyjskiego potencjału odstraszania. Bombowce Tu-160 są aktualnie modernizowane do standardu Tu-160M, oblot pierwszego zmodernizowanego samolotu miał miejsce 16 listopada 2014 roku. Eksploatacja i modernizacja tych maszyn napotyka jednak wiele trudności, między innymi ze względu na dawno zakończoną produkcję wielu ich komponentów, np. starzejących się i wymagających wymiany silników odrzutowych NK-32. Według niektórych źródeł w stanie pełnej zdatności do lotu znajduje się w Rosji zaledwie kilka samolotów (Jane’s World Air Forces, 2014, s. 44).

Rosja dysponuje także lżejszymi bombowcami Tu-22M3 (w kodzie NATO Backfire), które w ilości około 105 sztuk znajdują się w sześciu eskadrach lotnictwa dalekiego zasięgu. Nie są one jednak traktowane przez Rosjan jako samoloty strategiczne. Produkowano je w kilku wersjach, także rozpoznawczy, morski etc. W lotnictwie dalekiego zasięgu przenosi bomby i rakiety zarówno konwencjonalne, jak i z głowicami jądrowymi. Osiąga prędkość $2300 \mathrm{~km} / \mathrm{h}$ na dużej wysokości, a jego zasięg maksymalny wynosi 5,5 tys. km. Przeznaczony jest do wykonywania uderzeń jądrowych lub konwencjonalnych na cele w Europie i Azji, a w wersjach specjalistycznych, między innymi do zwalczania natowskich zespołów okrętowych i prowadzenia rozpoznania. Około 32 sztuki Tu-22M3 mają być zmodernizowane do nowszego standardu wraz z jednoczesnym przedłużeniem resursów, co powinno pozwolić tej partii samolotów służyć jeszcze przez wiele lat.

Poza modernizacją Tu-160 i Tu-22M3 Rosja prowadzi także kilka innych programów modernizacyjnych głównych składowych swojego lotnictwa strategicznego. Część ze starszych pocisków Ch-55 była przerabiana na wersję z głowicą konwencjonalną Ch-555, które osiągają wyższą precyzję rażenia i posiadają głowicę bojową o większej masie. Jest to uwarunkowane koniecznością rekompensaty znacząco niższej siły rażenia ładunku konwencjonalnego. Prawdopodobnie do jej przenoszenia przeznaczone będą w pierwszym rzędzie najstarsze Tu-95MS6, które tym samym zostaną wycofane ze strategicznych sił jądrowych. Z kolei Tu-95MS16 mają być unowocześnione do standardu Tu-95MSM, w oparciu o te same rozwiązania techniczne co w modernizowanym Tu-160M. Programom tym nadany jest w Rosji najwyższy priorytet Federalnego Programu Celowego. Ma on pozwolić na znaczące podniesienie możliwości bojowych samolotów, poprzez modernizację i wymianę awioniki, radaru oraz systemów nawigacyjnych, a przede wszystkim poprzez wprowadzenie nowego systemu uzbrojenia. Ma to być system planowania misji Sigma wraz z nową generacją rakiet nazwanych Ch-102 o podwyższonych w stosunku do poprzed- 
nika osiągach (Butowski, 2012, s. 65). Zakładany zasięg nowych rakiet (oznaczanych także jako Izdielije 504B) to nawet $4000 \mathrm{~km}$. Mają być dłuższe i cięższe od starszych Ch-55, rakieta Ch-102 ma mieć długość około 7,5 m i osiągać masę poniżej 2,5 tony. Z tego względu nie zmieszczą się wewnątrz komory bombowej Tu-95MS i przewiduje się, iż będzie on zabierać tylko 8 rakiet podwieszonych pod skrzydłami. Tu-160M ma mieć możliwość zabierania 12 rakiet wewnątrz kadłuba, gdyż już pierwotnie jego komory bombowe były opracowywane w celu pomieszczenia rakiet o większych rozmiarach. Kadłub rakiety Ch-102 ma mieć spłaszczony kształt celem uzyskania własności stealth, na wzór wycofanych już amerykańskich AGM-129A. Dzięki silnikowi turboodrzutowemu ma osiągać prędkość przelotową około $200 \mathrm{~m} / \mathrm{s}$. System naprowadzania kombinowany, integrujący system nawigacji bezwładnościowej, satelitarnej oraz podobnie jak w Ch-55 układ korekcji lotu wykorzystujący radiowysokościomierz do śledzenia profilu terenu i porównujący ją z zapisaną mapą w cyfrowej bazie danych. Według nieoficjalnych doniesień, pociski samosterujące Ch-102 od 2014 roku znajdują się już w produkcji seryjnej. Prowadzone są też prace nad konwencjonalną wersją rakiety oznaczoną Ch-101 (Izdielije 504A), lecz według wszelkiego prawdopodobieństwa nie mają one priorytetu i z tego względu znacząco się przedłużają.

W rosyjskich źródłach od kilku lat systematycznie pojawiają się doniesienia o planach podjęcia na nowo produkcji Tu-160, już w udoskonalonej wersji $\mathrm{Tu}-160 \mathrm{M} 2$. Taka deklaracja padła m.in. w kwietniu 2015 roku z ust ministra obrony Siergieja Szojgu, podczas jego wizyty w zakładach KAPO w Kazaniu. Niewątpliwie Rosji przydałaby się większa ilość tych samolotów, uzupełniająca ich stan do przynajmniej 30-36 sztuk jako najbardziej racjonalnej ilości. Pojawiają się również opinie o potrzebie zakupu nawet 40-50 tych samolotów, pozwalających na zastąpienie części starszych Tu-95MS i utrzymanie potencjału lotnictwa strategicznego do czasu wprowadzenia zupełnie nowego bombowca strategicznego. Aktualnie bowiem trwają w Rosji wstępne prace nad nowym ciężkim bombowcem. W konkursie na przyszłościowy bombowiec strategiczny dla Lotnictwa Dalekiego Zasięgu - PAK DA zwyciężył projekt Biura Konstrukcyjnego im. Tupolewa. Po rozważeniu wielu wariantów odrzucono projekty zakładające stworzenie samolotu o wysokiej prędkości naddźwiękowej, rzędu nawet 4,5 Ma. Przyszły bombowiec będzie konstrukcją poddźwiękową o ograniczonej wykrywalności, prawdopodobnie w układzie latającego skrzydła. W tym sensie zapewne będzie powielał ogólny układ konstrukcyjny amerykańskiego B-2A. W bardzo optymistycznym wariancie wstępnie rozpoczęcie produkcji PAK 
DA deklarowano na 2020 rok, choć realnie należy zakładać termin co najmniej 5, a nawet 10 lat późniejszy.

\section{KOMPONENT MORSKI STRATEGICZNYCH SIŁ JĄDROWYCH}

Na komponent morski strategicznych sił jądrowych składają się wyłącznie strategiczne okręty podwodne nosiciele rakiet balistycznych (OPARB). Znajdują się one w składzie dwóch flot, Floty Oceanu Spokojnego i Floty Północnej. Siły te stanowią integralną część rosyjskiej marynarki wojennej (WMF - Wojenno-Morskij Fłot).

W 1952 roku Rada Ministrów ZSRR wydała postanowienie o budowie atomowych okrętów podwodnych (AOP), a pierwszy okręt $z$ takim napędem zwodowano w 1957 roku. Z kolei w 1955 roku po raz pierwszy w ZSRR wystrzelono z pokładu wynurzonego okrętu podwodnego rakietę balistyczną (Usenko i in., 2004, s. 164-165). Naturalną konsekwencją rozwoju zarówno AOP, jak i rakiet balistycznych było powstanie w kolejnych latach atomowych okrętów podwodnych z rakietami balistycznymi (OPARB). Odpowiednia uchwała Rady Ministrów ZSRR w sprawie podjęcia budowy tego typu okrętów została podjęta w 1956 roku. Od początku swego istnienia OPARB stały się jednym ze środków odwetowego ataku jądrowego na terytorium przeciwnika. Operując na rozległych akwenach i ukrywając się w głębinach, OPARB były trudne do zniszczenia w ataku wyprzedzającym. Nawet w przypadku całkowitego unicestwienia państwa przez niespodziewany atak nuklearny przeciwnika, dzięki tym okrętom można było wykonać uderzenie odwetowe, niszcząc tym samym agresora.

Początkowo umożliwiały one ZSRR wykonywanie uderzeń wyłącznie na duże obiekty typu centra administracyjno-gospodarcze Stanów Zjednoczonych. Wiązało się to z tym, iż celność rakiet wystrzeliwanych spod wody, z niestacjonarnego obiektu, jakim jest okręt podwodny, nie była zbyt wysoka. Ich precyzja była jednak na tyle wystarczająca, aby zniszczyć duży obiekt, np. aglomerację miejską, stąd też ich przydomek „city killers”. Inną ich zaletą z punktu widzenia ZSRR było to, iż okręty, pływając w pobliżu wybrzeży USA, nie dawały atakowanemu dużo czasu na reakcję. Było to uwarunkowane stosunkowo krótkim czasem lotu rakiet, w porównaniu do tych wystrzeliwanych z kontynentu. Wraz z rozwojem technologii rakietowych w toku „zimnej wojny” okręty okazały się doskonałym środkiem do zwalczania również celów o znacznie mniejszych wymiarach. A gwarantowana przez nie możliwość wykonania uderzenia odwe- 
towego przyczyniła się do powstania sytuacji, kiedy to żadnej ze stron nie opłaca się zaatakować jako pierwszej. Mechanizm ten można sprowadzić do prostej sentencji, iż kto uderzy pierwszy, umrze drugi.

W celu wykrywania zbliżających się do wybrzeży USA radzieckich okrętów podwodnych z rakietami balistycznymi NATO stworzyło barierę na linii łączącej Grenlandię, Islandię, Stany Zjednoczone i Wielką Brytanię (SOSUS). Początkowo wszystkie radzieckie OPARB, chcąc podejść do wybrzeży USA, musiały ją przekroczyć, narażając się tym samym na wykrycie przez różnego rodzaju czujniki bariery rozmieszczone $\mathrm{w}$ głębinie. Pierwszym radzieckim okrętem wyposażonym w rakiety balistyczne, który wszedł do eksploatacji w znaczącej liczbie i który dzięki zwiększonemu zasięgowi swych rakiet nie musiał przekraczać tej bariery, był okręt projektu 667 i jego późniejsze modyfikacje B, BD, BDR oraz BDRM, (w kodzie NATO oznaczane kolejno jako Delta I, II, III i IV). Już typ 667B (Delta I) z rakietami SS-N-8 o zasięgu 7800 km miał możliwość atakowania głównych miast USA bez konieczności przekraczania bariery, na przykład ze stosunkowo bezpiecznych wód arktycznych.

Współcześnie w marynarce rosyjskiej w eksploatacji znajdują się strategiczne okręty podwodne czterech typów. Flota Pacyfiku posiada trzy okręty typu 667BDR Kalmar (oznaczenie NATO: Delta III). Pierwotnie przenosiły one po 16 dwustopniowych rakiet na paliwo ciekłe R-29R (oznaczenie NATO: SS-N-18 Stingray), każda wyposażona w 3 głowice jądrowe o mocy 50 kt. Aktualnie na ich pokładach znajdują się zmodyfikowane rakiety typu R-29RM Wołna na paliwo ciekłe (inne oznaczenie RSM-50, oznaczenie NATO: SS-N-18 M1 Stingray) (Ballistic \& Missile Threat, 2013, s. 22-25). W związku z tym, iż są to najstarsze okręty we flocie (budowane w latach 1976-1982), planowane jest wycofanie ich w najbliższej przyszłości.

Najnowocześniejsza modyfikacja projektu, 667BDRM Delfin (Delta IV), jest dużym okrętem podwodnym o wyporności 11,7 tys. ton i długości $164 \mathrm{~m}$. Wprowadzono go na uzbrojenie Floty Północnej w 1985 roku. Obecnie posiada ona 6 okrętów, z czego 3 mają status operacyjny i przenoszą pociski balistyczne. W związku z wyczerpywaniem się resursów ${ }^{12}$ starszych typów rakiet w Rosji już samodzielnie podjęto na nowo produkcję zmodyfikowanych trójstopniowych rakiet pod oznaczeniem R-29RMU Siniewa (inaczej RSM-54, oznaczenie NATO: SS-N-23 Skiff) i ten model aktualnie znajduje się na uzbrojeniu okrętów typu Delta IV. Osiągają one zasięg 9 tys. km i przenoszą po 4 głowice jądrowe, każda

12 Zakładany w momencie konstruowania rakiet okres ich eksploatacji to 10 lat. 
o mocy 100 kt. Planowane jest dalsze utrzymanie typu Delfin w służbie, po przeprowadzeniu odpowiednich remontów, przedłużeniu resursu z 25 do 35 lat oraz przezbrojeniu w nowszą wersję rakiety R-29RMU2 Łainier.

Dotychczas najbardziej znanym rosyjskim OPARB był typ 941 Akuła (oznaczenie NATO: Typhoon). Jest to największy na świecie atomowy okręt podwodny o nietypowej konstrukcji. I być może właśnie ze względu na stopień skomplikowania, rozmiary oraz koszty eksploatacji okręty te nie służyły zbyt długo, pierwszy został wycofany już po 15 latach eksploatacji. Od 1981 do 1989 roku na stan WMF przyjęto 6 okrętów projektu 941, z czego do dzisiaj w służbie pozostał jeden, a dwa w rezerwie oczekują na decyzję o utylizacji. Nowatorstwo konstrukcji Akuły było ściśle związane ze zmianami uwarunkowań, w jakich miały działać rosyjskie OPARB. W związku z postępem w technice rakietowej, radzieckie okręty mogły wykonywać uderzenia na terytorium Stanów Zjednoczonych ze znacznie większego dystansu. Dzięki temu operowały pod osłoną własnych sił morskich, a prędkość oraz skrytość okrętu (w sensie generowania jak najmniejszych zmian pól fizycznych oraz hałasu) przestały mieć decydujące znaczenie. Ważniejsze stały się zdolność do długotrwałego operowania pod wodą i siła ognia. Niezbędna była też odpowiednia przestrzeń, żeby pomieścić większą ilość coraz potężniejszych rakiet. Dlatego też okręt ten został zbudowany w układzie dwóch równoległych kadłubów sztywnych, każdy o długości 130 m. Mogą one funkcjonować całkowicie niezależnie od siebie, np. w przypadku awarii lub uszkodzeń bojowych. Obejmuje je kadłub zewnętrzny, mieszczący część instalacji, w tym kontenery z rakietami i kształtujący ogólny widok okrętu. Skutkiem tego typ Typhoon, nazywany często podwodnym krążownikiem, ma bardzo dużą szerokość. Przy 175 m długości osiąga prawie 23 m szerokości, to jest około dwa razy więcej niż inne okręty tej klasy. Zaś jego wyporność podwodna to aż 48 tys. ton. Załoga licząca 160 marynarzy ma bardzo dobre, jak na okręt podwodny, warunki bytowania. Było to związane z zakładaną długością rejsów, mogących trwać nawet ponad 3 miesiące.

Akuły przenosily po 20 rakiet R-39 (inne ros. oznaczenie RSM-52, wg NATO: SS-N-20 Sturgeon). Miały one znacząco większe rozmiary od tych na typie Delta i kolejnych modyfikacjach. Każda z rakiet mogła przenosić 10 głowic na odległość do 8,3 tys. km. Jedyny obecnie okręt tego typu w służbie, TK-208 Dimitrij Donskoj, jest wykorzystywany do testów nowo wdrażanych rakiet R-30 Buława.

Najnowszym rosyjskim OPARB jest okręt projektu 955 Boriej (ang. Borey). Pierwszy okręt serii był budowany od 1996 roku i miał wejść na uzbrojenie WMF już w 2002 roku. Prace nad nim opóźniły się jednak znacząco, zarówno 
z przyczyn finansowych, jak i technicznych. Ostatecznie pierwszy okręt serii K-535 Jurij Dołgorukij został uroczyście przyjęty na stan Floty Północnej 10 stycznia 2013 roku. Początkowo, według źródeł rosyjskich, okręt nie był jeszcze uzbrojony w rakiety balistyczne. Realizowano na nim różnego rodzaju testy, związane głównie ze sprawiającym problemy systemem uzbrojenia z rakietami Buława. Typ Boriej osiąga mniejsze rozmiary od typu Typhoon, przy długości $170 \mathrm{~m}$ i szerokości 13,5 m wypiera na/pod wodą odpowiednio 14,7 i 24 tys. ton. Załoga okrętu liczyć ma 107 marynarzy, w tym 55 oficerów. Od września 2013 roku K-535 bazuje w Jagielnoj Gubie na Półwyspie Kola. Ważnym wydarzeniem w rozwoju najnowszych rosyjskich OPARB było pierwsze treningowe strzelanie z okrętu wyposażonego w pełną jednostkę ognia, zrealizowane w dniu 29 października 2014 roku na Morzu Barentsa. Według rosyjskiego ministra obrony, zakończyło się ono sukcesem i wszystkie głowice ćwiczebne trafiły w cele na poligonie Kura na Kamczatce (Richardson, 2014, s. 13). Oznacza to, że w praktyce zakończone zostały testy systemu uzbrojenia i Jurij Dołgorukij osiągnął wstępną gotowość operacyjną.

W lipcu 2014 roku do służby wszedł drugi Boriej - K-550 „Aleksander Newskij”. Trzeci okręt serii „Władimir Monomach” w tym czasie przechodził próby morskie, między innymi 10 września 2014 roku wystrzelił rakietę RSM-56 Buława. Zgodnie z aktualnymi planami WMF oba okręty mają zostać przydzielone w 2015 roku do Floty Pacyfiku i bazować w Wiliuczyńsku na Kamczatce. Zgodnie z kontraktem z 28 maja 2012 roku, w budowie znajdują się kolejne okręty. Począwszy od czwartego okrętu tego typu ${ }^{13}$, mają być budowane według zmodyfikowanego projektu 955A, przenoszącego zwiększoną do 20 ilość wyrzutni rakiet balistycznych. Okręty Typu 955 i 955A mają stanowić zupełnie nową jakość w rosyjskich siłach zbrojnych i zagwarantować utrzymanie potencjału odstraszania przez flotę przez najbliższe dziesięciolecia.

Zasadniczym uzbrojeniem okrętów typu Boriej są rakiety R-30 (inne ros. oznaczenie RSM-56 Buława, w kodzie NATO: SS-N-32) w ilości 16 sztuk, każda z 6 głowicami. Zostały one opracowane w Rosji w Moskiewskim Instytucie Techniki Cieplnej na bazie konstrukcji rakiet bazowania lądowego Topol M. Było to zresztą źródłem wielu problemów Buławy, głównie z racji braku doświadczenia biura konstrukcyjnego $\mathrm{z}$ rakietami morskimi. Za tym szły bowiem liczne

13 Planowana nazwa dla niego to „Kniaź Władimir”. Zgodnie z kontraktem zbudowanych ma zostać 5 okrętów w zmodyfikowanym wariancie 955A. 
problemy konstrukcyjno-technologiczne, co w efekcie skutkowało wysoką awaryjnością rakiet.

Dzisiejsze siły morskie Rosji są już tylko cieniem tych z czasów „zimnej wojny”. Po rozpadzie ZSRR Rosja wraz z terytorium utraciła część swych baz morskich oraz przemysłu okrętowego. W okresie tym siły morskie redukowano na masową skalę, a okrętów pozostawianych w służbie nie modernizowano. Ówczesne ograniczenia finansowe nie pozwalały na prowadzenie dalekich patroli, wskutek czego ich ilość uległa ograniczeniu, a poziom wyszkolenia załóg obniżył się drastycznie. Większość radzieckich OPARB została wycofana z eksploatacji, w 1997 roku na złomowanie czekało 121 atomowych okrętów podwodnych (Szulc, 2003, s. 39), choć nie były to wyłącznie nosiciele rakiet balistycznych. Stan pozostałych w eksploatacji okrętów systematycznie się pogarszał, stopniowo zagrażając bezpieczeństwu pływania. Według US Naval Intelligence w całym 2012 roku, rosyjskie strategiczne okręty podwodne wykonały zaledwie 5 patroli o długotrwałości w granicach 1-2 miesięcy każdy.

Obecnie w eksploatacji pozostało $12-14$ będących w najlepszym stanie okrętów, 3 typu Delta III, 6 Delta IV, 1 Typhoon oraz 2-4 właśnie wdrażane do służby typu Boriej (russianforces.org/navy/, 2013). O przydatności OPARB i sensie ich utrzymywania w służbie decyduje ich zasadnicze uzbrojenie, czyli rakiety balistyczne. W przypadku okrętów typu Delta IV ich rakiety R-29RM mają resurs używalności określony na 10 lat. Stąd też konieczność ciągłej produkcji rakiet w Rosji i ich wymiany na pokładach okrętów. Z kolei niektóre elementy rakiet R-39 na okrętach Typhoon były produkowane na Ukrainie. Ze względu na brak nowych rakiet, których produkcja w oparciu wyłącznie o przemysł rosyjski napotykała problemy, wystąpiła konieczność przedwczesnego wycofania części okrętów. Problemy z rakietami R-30 Buława były z kolei jednym z czynników wpływających na opóźnienie przejęcia do służby przez Wojenno-Morskij Fłot okrętów typu 955.

\section{DOKTRYNALNE ZASADY UŻYCIA BRONI JĄDROWEJ PRZEZ FEDERACJĘ ROSYJSKA}

W 1991 roku po rozpadzie ZSRR część arsenałów jądrowych dawnego mocarstwa pozostała poza granicami Rosji. Istniały obawy utraty kontroli nad częścią potencjału jądrowego, lecz wkrótce wszystkie byłe republiki uznały Rosję jako sukcesora Związku Radzieckiego i rozpoczęły przekazywanie jej broni jądrowej. 
Na Białorusi znajdowały się głównie mobilne wyrzutnie Topol M i do 1996 roku zostały one wycofane. W Kazachstanie stacjonowało 40 strategicznych bombowców Tu-95MS, lecz strony szybko doszły do porozumienia i do 1994 roku samoloty zostały przebazowane do Rosji (Butowski, 2014, s. 52).

Na Ukrainie bazowało 176 pocisków SS-18 i SS-19 w podziemnych silosach. Rakiety zostały wycofane w 1996 roku, a niszczenie silosów zakończono w 2001 roku. W momencie rozpadu ZSRR na Ukrainie znajdowały się także bombowce strategiczne, 23 lub 25 sztuk Tu-95MS oraz 19 Tu-160 wraz z uzbrojeniem do nich. Były one przedmiotem długotrwałych negocjacji, aż ostatecznie część samolotów została przez Rosję odkupiona ${ }^{14}$. W 184. gwardyjskim pułku lotniczym bombowców ciężkich w Pryłukach na Ukrainie, stacjonowały wszystkie znajdujące się w linii 19 sztuk Tu-160. 8 spośród nich sprzedano Rosji, 10 pocięto na złom, a jeden oddano do muzeum. Wówczas też 3/4 pilotów Tu-160 zdecydowało się wyjechać do Rosji. W 1006. pułku lotniczym bombowców ciężkich w m. Uzyn znajdowały się 23 bombowce Tu-95MS. 3 z nich sprzedano Rosji w 1998 roku, jeden oddano do muzeum, a pozostałe złomowano. Wraz z bombowcami Rosja pozyskała też 575 rakiet Ch-55. W ten sposób Rosja jako jedyna z byłych republik ZSRR została państwem atomowym, skupiając w swych rękach wszystkie głowice nuklearne oraz środki ich przenoszenia.

Oficjalne podejście Rosji do kwestii użycia broni jądrowej określone zostało w „Wojennej doktrynie Federacji Rosyjskiej”, przyjętej 21 kwietnia 2000 roku na początku pierwszej prezydentury Władimira Putina. Rosjanie oceniali, iż ówczesna sytuacja polityczno-militarna skutkuje zmniejszeniem prawdopodobieństwa wybuchu wojny na wielką skalę, w tym wybuchu wojny jądrowej. Jednocześnie podkreślali, iż broń jądrowa jest jednym z podstawowych środków zapewnienia bezpieczeństwa państwa. Deklarowano gotowość do utrzymywania potencjału jądrowego na poziomie gwarantującym zadanie niezbędnych strat dowolnemu agresorowi w każdych warunkach. Rosja pozostawiła sobie także prawo do użycia broni jądrowej w odwecie na zastosowanie przeciwko niej lub jej sojusznikom broni masowego rażenia (a więc nie tylko broni jądrowej), a także w sytuacji krytycznej dla bezpieczeństwa narodowego, w warunkach konwencjonalnej agresji na dużą skalę. Jednocześnie Rosjanie deklarowali, iż nie użyją broni

${ }^{14}$ Samoloty pozyskano w zamian za redukcję długu Ukrainy za surowce energetyczne wobec Rosji. Głównym przedmiotem zainteresowania Rosjan były nowocześniejsze bombowce Tu-160, w związku z czym odkupiono ich 8 sztuk oraz jedynie 3 sztuki Tu-95MS. 
nuklearnej wobec tych państw - sygnatariuszy Układu o nierozprzestrzenianiu broni jądrowej, które same jej nie posiadają.

Założenia mówiące o możliwości użycia broni jądrowej w odpowiedzi na agresję konwencjonalną o dużej skali świadczyły dobitnie o świadomości wśród decydentów słabości rosyjskich sił konwencjonalnych. Ówcześnie w gronie najwyższych władz, ale także wewnątrz armii rosyjskiej toczył się spór o miejsce i rolę Strategicznych Sił Jądrowych (SSJ). Istniały dwa główne poglądy, pierwszy, że należy inwestować i dbać o SSJ jako główny czynnik odstraszania i zapewnienia bezpieczeństwa Rosji. Przedstawicielem tej grupy był między innymi ówczesny minister obrony Rosji Igor Siergiejew. Drugie podejście, reprezentowane przez szefa Sztabu Generalnego gen. Anatolija Kwasznina, iż powinno się inwestować w wojska konwencjonalne. W szczególności w siły szybkiego reagowania, jako remedium na różnego rodzaju konflikty lokalne w pobliżu granic Rosji.

Mając świadomość, iż zarówno ze względów finansowych, jak i technicznych nie będą już w stanie konkurować na wszystkich polach z USA, Rosjanie postawili w pierwszym rzędzie na rozwój swojego potencjału odstraszania nuklearnego ${ }^{15}$. Priorytetem stała się rewitalizacja Rakietowych Wojsk Strategicznego Przeznaczenia $^{16}$, a także lotnictwa strategicznego i tych składników marynarki wojennej, które zapewniają zdolność wykonania zmasowanego uderzenia jądrowego. Zasadniczym celem było utrzymanie ich na takim poziomie, który zapewniłby wiarygodny poziom odstraszania i tym samym zachowanie strategicznej równowagi. Chcąc utrzymania parytetu z USA w dziedzinie zbrojeń jądrowych, Rosjanie podjęli szereg programów modernizacyjnych. Poza opracowywaniem i wdrażaniem nowych typów broni, reformy polegały także na modernizacji starszych systemów uzbrojenia dających perspektywę długotrwałej eksploatacji.

W czasach nam współczesnych, w Strategii Bezpieczeństwa Narodowego z 12 maja 2009 roku ocenia się, że w ostatnich latach pozycja Rosji się wzmacnia, a na jej obszarze ma miejsce proces stabilizacji. W dalszym ciągu jednak jako potencjalne zagrożenie dla Rosji na pierwszym miejscu wymieniane jest

${ }^{15}$ W marcu 2012 roku w ramach wymiany informacji do układu New START Rosja zadeklarowała posiadanie ogółem 494 wyrzutni rakiet wraz z 1492 głowicami jądrowymi. Z tego Strategiczne Wojska Rakietowe są w posiadaniu 332 operacyjnych systemów rakietowych pięciu typów, które mogą przenosić 1092 głowice. Komponent morski dysponował 11 strategicznymi okrętami podwodnymi z 96 pociskami nuklearnymi na pokładach, które przenoszą łącznie 336 głowic. Lotnictwo dalekiego zasięgu posiada 66 bombowców oraz około 200 sztuk strategicznej broni przeznaczonej dla nich.

${ }^{16}$ W czasie, gdy ministrem obrony był Igor Siergiejew (były dowódca RWSN), na ten rodzaj wojsk przeznaczano 50-80\% wszystkich rosyjskich wydatków na nowe uzbrojenie. Szerzej zob.: R. Śmigielski, Osierocona armia, Warszawa 2006, s. 45. 
NATO. Opracowana na bazie „Strategii...” jako dokumentu politycznego nowa doktryna wojenna została zatwierdzona przez prezydenta Miedwiediewa 5 lutego 2010 roku. W swych założeniach miała ona odpowiadać zmieniającej się sytuacji geopolitycznej oraz nowym uwarunkowaniom polityczno-militarnym. Jej zasadnicze tezy były zbliżone do tego, co można było przeczytać w doktrynie z 2000 roku. Rosjanie stwierdzili w niej, iż: „za główne wyzwanie uważa się przekazanie NATO globalnych funkcji w dziedzinie bezpieczeństwa, niezgodne z prawem międzynarodowym oraz zbliżenie infrastruktury wojskowej państw-członków NATO do granic Federacji Rosyjskiej, między innymi poprzez rozszerzenie bloku" (Wojennaja Doktrina Rossijskoj Federacji, 2013). Broń jądrowa jest w niej określana jako mająca zasadnicze znaczenie dla zapobiegania możliwości wybuchu nuklearnego konfliktu zbrojnego. Rosja zostawiła sobie prawo użycia broni jądrowej w odpowiedzi na atak nuklearny, a także atak konwencjonalny zagrażający istnieniu państwa. W doktrynie dokonano gradacji konfliktów zbrojnych i dopuszczono możliwość użycia broni jądrowej w dwóch najpoważniejszych przypadkach, tj. w warunkach konfliktu regionalnego lub wojny na dużą skalę. Nie powtórzono już jednak zobowiązania o nieużywaniu broni jądrowej wobec państw nienuklearnych.

\section{PODSUMOWANIE}

Począwszy od czasów N.S. Chruszczowa dominację w radzieckiej/rosyjskiej triadzie nuklearnej uzyskały i utrzymują ją do dziś Wojska Rakietowe Strategicznego Przeznaczenia, czyli lądowy komponent SSJ FR. Przejściowo były one nawet samodzielnym rodzajem sił zbrojnych. Brało się to przede wszystkim z tego, iż potencjał RWSN w zakresie zdolności do przenoszenia głowic nuklearnych, stanowił i stanowi zasadniczą część radzieckich/rosyjskich zdolności w tym zakresie. A zdolność do strategicznego odstraszania zawsze stała na czele listy priorytetów władz w Moskwie. W latach 1991-1997 Rosja przeznaczała gros dostępnych środków właśnie na ten rodzaj wojsk. Mimo że po zakończeniu zimnej wojny potencjał ilościowy RWSN uległ znaczącej redukcji, to i tak jest on najbardziej znaczący spośród pozostałych składników rosyjskiej triady nuklearnej. Dopiero w kolejnych latach Kreml zwiększał stopniowo nakłady na pozostałe składniki rosyjskiej triady. Obecnie praktycznie w każdym komponencie Strategicznych Sił Jądrowych Rosji prowadzone są prace nad nowymi środkami przenoszenia broni nuklearnej. Pomimo pewnych problemów, w komponencie morskim 
wdrażane są nowe okręty podwodne projektu Boriej oraz rakiety balistyczne Buława. Modernizuje się też starsze okręty proj. 677BDRM Delfin z rakietami Siniewa/Łainier. Na uzbrojenie Wojsk Rakietowych Strategicznego Przeznaczenia (RWSN) wchodzą kolejne, coraz to nowsze wersje mobilnych rakiet V pokolenia, prowadzone są też prace nad zupełnie nową ciężką rakietą bazującą w silosach. Dowództwo RWSN planuje zastąpić nimi do 2020 roku wszystkie rakiety balistyczne III i IV generacji, wywodzące się jeszcze z czasów ZSRR. Także lotnictwo dalekiego zasięgu modernizuje swoje bombowce strategiczne i wprowadza na ich uzbrojenie nową generację skrzydlatych rakiet manewrujących z głowicą jądrową. We wstępnej fazie prac znajduje się też projekt nowego bombowca strategicznego.

Wszystkie w/w programy będą wymagały olbrzymiego wysiłku finansowego państwa. Rosjanie zdają sobie sprawę, że nie będą w stanie zastąpić wycofywanych systemów uzbrojenia strategicznego nowymi w stosunku jeden za jeden. Ilość zakupywanych dla RWSN rakiet balistycznych, np. w latach 2011-2014, nie zabezpieczała możliwości uzupełniania stanów w miejsce wycofywanych systemów z przekroczonymi resursami eksploatacji. Stąd też takie działania jak wstrzymanie w 2013 roku decyzji o rozformowaniu trzech pułków rakiet z 28 Dywizji RWSN, należy oceniać jako rozwiązanie doraźne, związane ze wzrostem napięcia w Europie. W perspektywie kilku lat pułki te, wyposażone w rakiety RS-18 z przedłużonymi do 32 lat resursami eksploatacji, będą zapewne rozwiązane. Będzie się to wpisywało w ogólny trend redukcji sił, skutkujący w przyszłości pozostawieniem od 7 do 9 związków taktycznych (dywizji rakietowych) w RWSN.

Pomimo redukcji ilościowych realizowanych w zgodzie z kolejnymi edycjami traktatów o ograniczeniu zbrojeń strategicznych, broń jądrowa będzie tą kategorią uzbrojenia, która zachowa priorytet, jeśli chodzi o finansowanie ${ }^{17}$. Można oceniać, iż Rosja bez względu na koszty będzie starała się utrzymać swój potencjał odstraszania na wysokim, adekwatnym do posiadanego przez USA poziomie. Jest to bowiem współcześnie jedyna dziedzina, w której Federacja Rosyjska może realnie konkurować ze Stanami Zjednoczonymi. A wszelkie działania Rosjan w tej kwestii są podejmowane właśnie względem Stanów

$17 \mathrm{~W}$ marcu 2011 roku premier Rosji stwierdził, że w ramach programu modernizacji na lata 2011-2020, w ciągu kolejnych trzech lat na rozwój i produkcję broni rakietowej przeznaczone zostanie około 15 mld rubli, co powinno pozwolić na podwojenie produkcji techniki rakietowej w tym okresie. A w perspektywie 2020 r. wydatki na ten cel powinny zamknąć się sumą około 77 mld rubli. 
Zjednoczonych. Utrzymanie parytetu z USA pozwala Rosji zachować status mocarstwa atomowego, czyli jedyne, co pozostało Rosji w schedzie po byłym ZSRR. Zakładać można, iż w przyszłości przewartościowaniu ulec może znaczenie poszczególnych komponentów rosyjskiej triady nuklearnej. Przykładowo wobec spodziewanego wprowadzenia do służby ośmiu nowoczesnych OP klasy Boriej wzrosnąć może rola komponentu morskiego. Zauważalne stają się też tendencje do skonsolidowania poszczególnych komponentów triady pod jednym dowództwem, jak też zmiany ich podporządkowania. Coraz silniejsze są bowiem głosy wzywające do podporządkowania dowództwu RWSN lotnictwa dalekiego zasięgu. $Z$ drugiej jednak strony takie propozycje pojawiały się znacznie wcześniej, jeszcze w czasach ZSRR. Nigdy jednak władze na Kremlu nie zdecydowały się oddać całego swego potencjału nuklearnego w podporządkowanie jednemu dowództwu.

\section{BiBLIOGRAFIA:}

Ballistic \& Missile Threat, (2013). National Air and Space Intelligence Center, Wright-Patterson AFB: NASIC Public Affairs Office.

Butowski, P. (2012). Modernizacja rosyjskich bombowców strategicznych. Nowa Technika Wojskowa, 06/2012, Warszawa: Wydawnictwo Magnum-X.

Butowski, P. (2014). Tupolew Tu-95 - naczelny strateg. Nowa Technika Wojskowa, 05/2002, Warszawa: Wydawnictwo Magnum-X.

Dane odnośnie rosyjskich sił powietrznych (2013). Pobrane z: http://russianforces.org/ aviation/.

Dane odnośnie do rosyjskiej marynarki wojennej (2013), Pobrane z http://russianforces. org/navy/.

Mikołajczuk, M. (2003). Powstanie i rozwój Strategicznych Wojsk Rakietowych ZSRS i Federacji Rosyjskiej w latach 1945-2003. Nowa Technika Wojskowa, 08/2003, Warszawa: Wydawnictwo Magnum-X.

Reed, T.C., Stillman, D.B. (2009). The Nuclear Express: A Political History of the Bomb and Its Proliferation, Minneapolis: Zenith Press.

Richardson, D. (2014). Russian Navy conducts first Bulawa training launch. IHS Jane's International Defence Review, Vol. 47, December 2014.

Russia Air Forces, (2014). Jane's World Air Forces 2014.

SIPRI Yearbook 2013: Armament, Disarmament and International Security, (2013), Oxford University Press.

Śmigielski, R. (2006). Osierocona armia, Warszawa: Wydawnictwo TRIO.

Strona MO Federacji Rosyjskiej (2013). Pobrane z: http://structure.mil.ru/structure/ forces/strategic_rocket/history.htm http://structure.mil.ru/structure/forces/strategic_rocket/weapons.htm. 
Szulc, T. (2003). Marynarka Wojenna Rosji. Nowa Technika Wojskowa, 10/2003, Warszawa: Wydawnictwo Magnum-X.

The Military Balance (2013). London: The International Institute for Strategic Studies. Usenko, N.W., Kotow, P.G., Riedanskij, W.G., Kuliczkow, W.K. (2004). Kak sozdawałsa atomnyj powodnyj ftot Sowietskowo Sojuza. Moskwa.

Wojennaja Doktrina Rossijskoj Federacji, (2013). Pobrane z: http://www.nationalsecurity.ru/library/00003/index.htm.

Woskriesieńskij, S. (2015). Tiażełyj słuczaj. Technika i worużienije nr 4/2015, s. 11. 